\title{
Tinjauan Yuridis Setoran Bea Perolehan Hak Atas Tanah dan Bangunan Secara Online
}

\author{
I Dewa Bagus Dhanan Aiswarya ${ }^{1}$ \\ ${ }^{1}$ Program Studi Magister (S2) Kenotariatan Fakultas Hukum Universitas Udayana, \\ E-mail: bagusdhanan15@gmail.com
}

\begin{tabular}{l}
\hline Info Artikel \\
\hline Masuk : 18 Juli 2019 \\
Diterima : 13 Agustus 2019 \\
Terbit : 30 Desember 2019 \\
Keywords : \\
Tax; Transition of Rights; \\
Online \\
\\
\\
Kata kunci: \\
Pajak; Peralihan Hak; Online \\
Corresponding Author: \\
I Dewa Bagus Dhanan \\
Aiswarya, E-mail: \\
bagusdhanan15@gmail.com \\
DOI: \\
10.24843/AC.2019.v04.i03.p04
\end{tabular}

10.24843/ AC.2019.v04.i03.p04

\begin{abstract}
Land and Building Acquisition Fees (BPHTB) is one of the various types of taxes that must be collected based on Act Number 21 of 1997 concerning Land and Building Acquisition Fees. Law Number 20 of 2000 concerning Amendments to Law Number 21 of 1997. Based on these two rules, it is stated that BPHTB deposits must be made online. What is the background for BPHTB deposits to be made online? Then what is the payment procedure? Moving on from these two problems, the goal to be achieved in this article is to find out and analyze the background and procedures for depositing ВРНТВ online. This paper is doctrinal and uses two types of approaches, statues approach and conceptual approach. Sources of legal material were obtained through literature methods and then analyzed qualitatively. The conclusions of this paper; (1) background of depositing BPHTB online that is to facilitate the public to make payments to the Acquisition Fee for Building Land Rights both because of the transaction of buying, inheritance and will, and (2) The process of depositing BPHTB online is divided into several stages. These stages are not all stages that use electronic media, manual stages such as the collection of physical data used for research and then end with the legalization process done manually.
\end{abstract}

\begin{tabular}{l}
\hline Abstrak \\
\hline Bea Perolehan Hak Atas Tanah dan Bangunan (BPHTB) \\
merupakan salah satu dari sekian jenis pajak yang wajib \\
dipungut berdasarkan Undang-Undang Nomor 21 Tahun 1997 \\
Tentang Bea Perolehan Hak Atas Tanah dan Bangunan jo. \\
Undang-Undang Nomor 20 Tahun 2000 Tentang Perubahan \\
Atas Undang-Undang Nomor 21 Tahun 1997. Berdasarkan dua \\
aturan tersebut, ditegaskan bahwa penyetoran BPHTB harus \\
dilakukan secara online. Apakah yang menjadi latar belakang \\
sehigga penyetoran BPHTB harus dilakukan online? Lalu \\
bagaimana prosedur pembayarannya? Beranjak dari dua \\
permasalahan tersebut, maka tujuan yang ingin dicapai dalam \\
artikel ini ialah untuk mengetahui dan menganalisis latar \\
belakang serta prosedur penyetoran BPHTB secara online. \\
Tulisan ini bersifat doktrinal dan menggunakan 2 jenis \\
pendekatan, statues approach dan conceptual approach. Sumber \\
bahan hukum diperoleh melalui metode kepustakaan dan \\
selanjutnya dianalisis secara kualitatif.Adapun kesimpulan dari \\
tulisan ini; (1) latar belakang penyetoran BPHTB secara online \\
yaitu untuk memudahkan masyarakat untuk melakukan
\end{tabular}


pembayaran terhadap Bea Perolehan Hak Tanah Bangunan baik karena traksaksi jual-beli, waris dan hibah wasiat, (2) Proses penyetoran BPHTB secara online terbagi dalam beberapa tahapan. Tahapan tersebut tidak semuanya tahapan yang mempergunakan media elektronik, tahapan manual seperti pengumpulan data-data fisik yang dipergunakan untuk penelitian lalu di akhiri dengan proses legalisir dikerjakan secara manual.

\section{Pendahuluan}

Bea perolehan Hak atas Tanah dan Bangunan yang selanjutnya disingkat dengan BPHTB merupakan jenis pajak yang baru diterapkan di Indonesia seiring dengan penggalian potensi baru dalam hal perpajakan. Namun sesungguhnya, BPHTB merupakan jenis pajak lama yang pernah dipungut pada masa pemerintahan penjajah tetapi dihapus seiring dengan berlakunya Undang-Undang Nomor 5 Tahun 1960 tentang Peraturan Dasar Pokok-Pokok Agraria selanjutnya disebut UUPA, dan kemudian ditetapkan kembali karena dianggap sesuai dengan keadaan Bangsa Indonesia dewasa ini. BPHTB merupakan jenis pajak yang dihidupkan kembali dalam hal balik nama atas pemilikan tanah dan bangunan.

Ordonansi Bea Balik Nama Harta tetap atau Staatblad 1924 Nomor 291 merupakan pengaturan BPHTB masa lampau, atau dapat dikatakan historis. Setiap orang yang memperoleh hak atas tanah akan dibebani pajak yang disebut dengan bea balik nama harta tetap, hal ini pertama kali berlaku pada tahun 1924. Muhammad Rusjdi berpendapat bahwa Ordonansi Bea Balik Nama Harta Tetap mengenakan pajak atas, pertama semua perjanjian harta tetap yang terletak atau berada di Indonesia, kedua akta pendaftaran dan pemindahan kapal, dan ketiga semua peralihan karena warisan atau legaat dari harta tetap atau kapal yang terdaftar yang ditinggalkan oleh orang-orang yang mempunyai tempat tinggal terakhir di Indonesia. ${ }^{1}$

Undang-Undang Nomor 21 Tahun 1997 jo Undang-Undang Nomor 20 Tahun 2000 merupakan dasar hukum dari pengenaan BPHTB. Ketentuan mengenai objeknya dapat ditemukan pada memori penejelasannya yakni tanah yang merupakan Karunia Tuhan memiliki beberapa fungsi yakni fungsi sosial, fungsi ekonomi yang berfungsi selain menjadi pemenuhan kebutuhan papan juga dapat menjadi alat investasi yang dapat memberikan keuntungan. Pahala Siahaan berpendapat bahwa wajib setoran BPHTB diperuntukkan bagi orang yang memperoleh hak atas tanah dan bangunan, orang yang menerima tersebut dikategorikan sebagai wajib pajak dan menyetorkannya kepada negara melalui lembaga keuangan yang telah diberikan wewenang untuk memfasilitasi proses tersebut. ${ }^{2}$ Beranjak dari hal tersebut objek BPHTB adalah perolehan hak atas tanah dan bangunan, adapun yang dimaksud dengan perolehan hak atas tanah dan bangunan yang dijadikan objek BPHTB, dapat ditelusuri dari pengertian perolehan hak atas tanah termasuk tanaman dan bangunan yang ada di atasnya, yang dilihat sebagai salah satu kesatuan.

\footnotetext{
${ }^{1}$ Rusjdi, M. (2005). PBB, BPHTB \& BEA MATERAI; Pajak Bumi dan Bangunan, Bea Perolehan Hak atas Tanah dan Bangunan, \& Bea Materai. Jakarta: PT. Indeks, h. 126.

${ }^{2}$ Siahaan, M.P. (2003). Bea Perolehan Hak Atas Tanah dan Bangunan. Jakarta:Raja Grafindo Persada. h. 60.
} 
Ketentuan Pasal 2 ayat (3) Undang-Undang Nomor 20 Tahun 2000 menyebutkan, yang menjadi obyek BPHTB yaitu Hak Milik, Hak Guna Usaha, Hak Pakai, Hak Milik Atas Satuan Runah Susun dan Hak Pengelolaan. Hak atas tanah selain yang disebutkan di atas bersifat sementara. Hak sementara tersebut antara lain hak gadai, hak guna usaha bagi hasil dan hak menumpang, sekalipun sifatnya yang sementara akan tetapi tetap dapat mengikat seseorang dengan tanah dan bangunan. Tiga hak sementara ini tidak termasuk hak atas tanah yang menjadi objek BPHTB..

Pembahasan dalam BPHTB juga tidak luput dari pembahasan subyek BPHTB, wajib pajak yang memperoleh tanah dan bangunan akan menjadi subyek BPHTB, baik berupa orang atau badan hukum. Pemungutan BPHTB diatur dalam Pasal 10 ayat (1) Undang-Undang Nomor 20 Tahun 2000, metode yang dipergunakan adalah self assessment. Metode ini merupakan metode yang baru dikembangkan tanpa mempergunakan surat ketetapan pajak. Wajib pajak menyetorkan sendiri BPHTB yang menjadi kewajibannya. Self assessment memberikan kepercayaan kepada wajib pajak untuk menghitung dan membayar sendiri, dalam proses penyetoran BPHB menggunakan Surat Setoran Bea Perolehan Hak Atas Tanah dan Bangunan.

Pasal 9 Undang-Undang Nomor 20 Tahun 2000 mengatur bahwa “BPHTB terhutang harus dibayar pada saat Akta pemindahan hak atas tanah dan bangunan ditandatangani oleh Pejabat Pembuat Akta Tanah (PPAT); Risalah Lelang yang membuat penunjukan pemenang lelang ditandatangani oleh Kepala Kantor Lelang/ Pejabat Lelang; Dilakukan Pendaftaran hak oleh Kepala Kantor Pertanahan Kabupaten/Kota dalam hal pemindahan hak karena pelaksanaan putusan hakim yang telah mempunyai kekuatan hukum tetap, waris, maupun hibah wasiat; Diterbitkannya surat keputusan pemberian hak baru baik sebagai kelanjutan pelepasan hak maupun diluar pelepasan hak oleh Kepala Kantor Pertanahan Kabupaten/Kota."

Dengan demikian peralihan hak atas tanah harus dilaksanakan dihadapan Pejabat Pembuat Akta Tanah (PPAT) dan dibuatkan akta peralihan hak oleh PPAT. Perolehan hak atas tanah yang dilakukan dihadapan PPAT tersebut untuk mendapatkan kepastian hukum maka harus didaftrakan pada Kantor Pertanahan Kabupaten/Kota setempat letak objek tanah, selambat-lambatnya 7 (tujuh) hari kerja sejak ditandatangani akta tersebut oleh pihak-pihak, saksi-saksi dan PPAT.

PPAT sebagai pejabat umum diberikan kewenangan untuk membuat akta-akta otentik mengenai perbuatan hukum tertentu terhadap hak-hak atas tanah. Arti penting PPAT dapat dilihat dari ketentuan Pasal 37 Peraturan Pemerintah Nomor 24 Tahun 1997 tentang "Pendaftaran Tanah, peralihan hak atas tanah dan Hak Milik Atas Satuan Rumah Susun melalui jual beli, tukar menukar, hibah, pemasukan dalam perusahaan, danperbuatan hukum pemindahan hak lainnya, kecuali pemindahan hak melalui lelang, hanya dapat didaftarkan jika dibuktikan dengan akta yang dibuat oleh PPAT yang berwenang menurut ketentuan peraturan perundang-undangan yang berlaku." Kewenangan PPAT diatur dalam Peraturan Pemerintah Republik Indonesia Nomor 24 Tahun 2016 Tentang Perubahan Atas Peraturan Pemerintah Nomor 37 Tahun 1998 tentang Peraturan Jabatan Pejabat Pembuat Akta Tanah.

Kewajiban melakukan pembayaran BPHTB oleh wajib pajak berlaku di seluruh Indonesia, tidak terkecuali di Kota Denpasar. Pengaturan mengenai BPHTB Kota Denpasar terdapat pada Peraturan Daerah Kota Denpasar Nomor 7 Tahun 2010 Tentang Bea Perolehan Hak Atas Tanah dan Bangunan. Perda Kota Denpasar ini 
mengatur pedoman-pedoman dalam proses pengenaan BPHTB untuk wajib pajak. Namun terdapat hal-hal teknis yang belum diatur dalam Perda Kota Denpasar Nomor 7 Tahun 2010 sehingga Perda ini memerlukan peraturan pelaksanaan.

Peraturan pelaksanaan yang mengatur tentang tata cara pembayaran dan pelaporan BPHTB termuat dalam Peraturan Walikota Denpasar Nomor 17 Tahun 2016. Tata cara pembayaran BPHTB pada peraturan walikota ini mempergunakan sistem online. Pihak-pihak terkait yang dapat melakukan pembayaran dan penyetoran BPHTB adalah wajib pajak dan prosesnya melalui PPAT. Setiap wajib pajak dapat memilih PPAT di Kota Denpasar untuk melakukan proses pembayaran BPHTB. PPAT tersambung dalam sebuah sistem informasi yang disediakan oleh Dinas Pendapatan dan dalam sistem tersebut juga terintegrasi dengan Bank Pembangunan Daerah Bali (BPD Bali) untuk memfasilitasi proses penyetoran BPHTB.

Pesatnya kemajuan ilmu pengetahuan serta teknologi membuat setiap aktivitas dari berbagai kalangan dapat terbantu, berbagai pekerjaan dapat diselesaikan lebih cepat oleh penggunaan sistem informassi dan sistem media yang baru dengan teknologi yang tinggi. ${ }^{3}$ Penggunaan media elektronik yang disebut dengan ruang siber (cyber space) dewasa ini menjadi konsumsi primer bagi setiap orang. Ruang siber yang tergolong virtual dipergunakan sebagai sarana perbuatan hukum nyata untuk mempermudah berbagai proses. Termasuk proses penyetoran BPHTB di Kota Denpasar. Pemanfaatan ruang siber diharapkan mampu memberikan transparansi pembayaran, kemudahan proses dan mempersingkat waktu dari penyetoran BPPHTB.

Artikel ilmiah/jurnal yang membahas mengenai penyetoran BPHTB pernah diterbitkan oleh beberapa penulis. Rini Irianti Sundary menerbitkan jurnal yang berjudul Pengalihan Bea Perolehan Hak Atas Tanah dan Bangunan (BPHTB) dari Pajak Pusat Menjadi Pajak Daerah Sebagai Upaya Peningkatan Pendapatan Asli Daerah (PAD), rumusan masalah jurnal tersebut antara lain bagaimanakah pengalihan BPHTB dari pajak pusat menjadi pajak daerah dalam hubungannya dengan prinsip-prinsip umum perpajakan daerah ? dan sejauh mana pemungutan BPHTB sebagai pajak daerah dalam meningkatkan Pendapatan Asli Daerah (PAD) ?. ${ }^{4}$ Jurnal berikutnya ditulis oleh Meilan Agu yang berjudul Evaluasi Penerapan Sistem Pajak Bea Perolehan Hak Atas Tanah dan Bangunan (BPHTB) Sebagai Pajak Daerah Pada Dinas Pendapatan Daerah Kabupaten Minahasa Tenggara, rumusan masalah jurnal ini adalah bagaimana penerapan sistem pelaksanaan pemungutan Pajak Bea Perolehan Hak Atas Tanah dan Bangunan di Kabupaten Minahasa Tenggara ? dan Faktor - faktor penghambat apa saja yang di hadapi pemerintah daerah Kabupaten Minahasa Tenggara dalam penerapan sistem pelaksanaan pemungutan Pajak Bea Perolehan Hak Atas Tanah dan Bangunan ?, dengan memberikan referensi artikel ilmiah/jurnal terkait yang telah terbit maka akan menunjukan sebuah pembaharuan ilmiah dan menghindarkan dari tindakan plagiasi.

\footnotetext{
${ }^{3}$ Sidik, S. (2013). Dampak Undang-undang Informasi dan Transaksi Elektronik (ITE) Terhadap perubahan Hukum dan Sosial Dalam Masyarakat. Jurnal Ilmiah WIDYA Fakultas Hukum Universitas Bhayangkara Jakarta Raya, 1(1) 2338-3321.

${ }^{4}$ Sundary, R.I. (2018). Pengalihan Bea Perolehan Hak Atas Tanah dan Bangunan (BPHTB) dari Pajak Pusat Menjadi Pajak Daerah Sebagai Upaya Peningkatan Pendapatan Asli Daerah (PAD). Aktualita 1(1). 279-294.
} 


\section{Metode Penelitian}

Artikel ini merupakan penelitian hukum normatif (doktrinal). Penelitian hukum normatif yang lebih spesifik membahas mengenai peraturan perundang-undangan atau disebut juga yuridis normatif. Penelitian yuridis akan meneliti berbagai peraturan-peraturan hukum yang ada kaitannya dengan permasalahan yang akan dibahas. Aspek normatifnya adalah penelitian terhadap asas hukum yang berlaku dan bersumber kepada kepustakaan. Pendekatan perundang-undangan atau statues approach dan pendekatan konseptual atau conseptual approach akan dipergunakan dalam penelitian ini. Metode pengumpulan bahan hukum yang akan dipergunakan adalah berbanding lurus dengan metode pendekatan yakni pendekatan perundangundangan dan pendekatan konsep.

Pendekatan perundang-undangan artinya peneliti harus mencari peraturan perundang-undangan terkait dan pendekatan konseptual mewajibkan peneliti mengumpulkan konsep-konsep dari buku-buku hukum. Langkah selanjutnya yang dilakukan oleh peneliti adalah mengetik di komputer semua bahan yang telah diperoleh, kemudian membuat folder yang diberi subjek tujuannya untuk memudahkan dalam pencarian bahan-bahan yang telah terkumpul dalam proses penelitian.

\section{Hasil dan Pembahasan}

\subsection{Latar Belakang Dilakukannya Proses Setoran Bea Perolehan Hak Atas Tanah dan Bangunan Secara Online}

Perbuatan hukum dan/atau peristiwa hukum merupakan penyebab adanya proses peralihan hak atas tanah dan bangunan, dengan beberapa persyaratan yang harus dipenuhi sebelum atau saat proses peralihan hak atas dan bangunan terjadi. Persyaratan-persyaratan yang dimaksud adalah munculnya pajak-pajak akibat peralihan hak yang harus dibayar terlebih dahulu sebelum hak atas tanah beralih. Mengenai peralihan hak terdapat 3 (tiga) pajak terkait yang harus dilunasi oleh yang melepaskan hak atau penerima hak yaitu, PBB yang merupakan akronim dari Pajak Bumi dan Bangunan. Bea perolehan Hak Tanah dan Bangunan (BPHTB) yang diperuntukan bagi orang atau badan hukum yang memperoleh hak dan pajak penghasilan disebut juga PPH yang merupakan pajak penghasilan atas penjualan tanah dan atau/ bangunan. Bagi yang melepaskan hak, pajak yang harus dilunasi adalah PBB atas tanah dan atau bangunan yang akan dilepaskan dan PPH atas penjualan tanah dan atau bangunan. Bagi penerima atau yang memperoleh hak pajak yang harus dibayar adalah BPHTB sebagai kewajiban dari perolehan ha katas tanah dana tau bangunan yang telah diterima.

Berdasarkan jenis pajak yang telah diuraikan, penelitian ini membatasi pada pajak yang timbul akibat dari adanya peralihak hak atas tanah dan bangunan yaitu BPHTB. Wajib pajak yang memperoleh hak atas tanah baik orang atau badan hukum diwajibkan untuk melakukan penyetoran BPHTB. Penyetoran BPHTB ini dilunasi dengan mendapatkan tanda bukti setor pajak yang disebut dengan Surat Setoran Bea Perolehan Hak Atas Tanah dan Bangunan atau biasa disebut dengan SSB. SSB inilah yang dipergunakan sebagai bukti pembayaran BPHTB dan selanjutnya dipergunakan sebagai salah satu syarat dalam proses peralihan hak atas tanah. 
BPHTB merupakan pajak yang dikenakan atas perolehan atas hak dan bangunan.

Marihot Siahaan berpendapat bahwa pungutan pajak akan menimbulkan beban bagi masyarakat, sehubungan dengan hal tersebut harus memperoleh persetujuan oleh masyarakat melalui perwakilan masyarakat yaitu Dewa Perwakilan Rakyat dan dituangkan dalam bentuk undang-undang. ${ }^{5}$ Apabila pada tingkat Kabupaten/Kota khususnya Kota Denpasar maka persetujuan masyarakat diwakili oleh Dewan Perwakilan Rakyat Daerah (DPRD) Kota Denpasar, lalu menghasilkan produk hukum yaitu Peraturan Daerah Kota Denpasar. Pembuatan pengaturan mengenai pajak baik berupa undang-undang maupun peraturan daerah, didalamnya berisikan ketentuanketentuan yang mengikat untuk umum, maka dari itu proses pembentukannya harus dilakukan dengan cermat dan hati-hati.

Dasar hukum penyetoran BPHTB di Kota Denpasar diatur dalam Peraturan Daerah Kota Denpasar Nomor 7 Tahun 2010 Tentang Bea Perolehan Hak Atas Tanah dan Bangunan. Perda Kota Denpasar ini mengatur mengenai subyek dan obyek BPHTB, dasar pengenaan, tarif dan cara penghitungan pajak, wilayah dan saat terhutangnya pajak, tat acara pembayaran, pengembailan kelebihan bayar pajak, kedaluwarsa, sanksi administratif, ketentuan penyidikan serta ketentuan pidana.

Metode penyetoran BPHTB berdasarkan Perda Kota Denpasar Nomor 7 Tahun 2010 masih mempergunakan blangko sebagai acuannya, atau dapat diartikan sebagai metode manual. Mekanisme manual tersebut mengalami pergeseran seiring dengan kemajuan teknologi, sehingga pada era cyberspace ini mekanisme penyetoran BPHTB turut mempergunakan sistem online. Dasar hukum yang melandasinya melalui Peraturan Walikota Denpasar Nomor 17 Tahun 2016 Tentang Tata Cara Pelaksanaan Pembayaran dan Pelaporan Bea Perolehan Hak Atas Tanah dan Bangunan (BPHTB) secara online. Pengaturan penyetoran BPHTB secara online ini selain mempertimbangkan media yang dipergunakan, secara filosofis pengaturan ini dikeluarkan dalam rangka memudahkan masyarakat untuk melakukan pembayaran terhadap Bea Perolehan Hak Tanah Bangunan, baik karena transaksi jual-beli, waris, dan hibah wasiat (Ketentuan Menimbang huruf a. Peraturan Walikota Denpasar Nomor 17 Tahun 2016).

Runtutan proses penyetoran BPHTB mengakomodir beberapa perbuatan hukum yakni jual-beli, hibah dan waris. Tiga perbuatan hukum mengenai perpindahan hak atas tanah ini paling lumrah dilakukan serta terdapat penyetoran BPHTB pada rangkaian proses peralihan haknya. Perbedaan proses penyetoran BPHTB pasca tahun 2016 penekanannya kepada media yang digunakan. Sehingga dengan sistem online terdapat arsip yang dapat diakses kapanpun dan dimanapun baik pada saat proses input data maupun sebagai daftar riwayat penyetoran BPHTB. Selain itu juga dapat mempersingkat waktu rangkaian penyetoran BPHTB, karena jika dirunut dari awal mulai dari mengumpulkan data para pihak baik itu penerima hak dan pemberi hak, memasukkan data di dalam blangko yang disediakan oleh Dinas Pendapatan (selanjutnya disingkat dispenda) Kota Denpasar, penyetoran kepada bank, sampai beberapa proses revisi hingga blangko BPHTB tersebut telah di legalisir oleh Kepala Kantor Dispenda Kota Denpasar.

Pertimbangan selain untuk mempermudah masyarakat untuk melakukan pembayaran BPHTB adalah memberikan transparansi dalam transaksi dari PPAT. Melalui sistem

\footnotetext{
${ }^{5}$ Siahaan, M.P. Op.Cit, h. 39.
} 
online wajib pajak baik penerima hak maupun pemberi hak mengetahui perhitungan BPHTB yang akan dibayarkan. Data dari suatu objek tanah sudah terekam dalam sistem melalui Nomor Objek Pajak (NOP). NOP tersebut mengandung data-data antara lain luas tanah, luas bangunan jika ada, dan kolom yang berisikan kewajiban pembayaran Pajak Bumi dan Bangunan(PBB). Transparansi dan pengawasan akan terlihat pada sistem penghitungan dan pembayaran yang sudah secara langsung tertera dalam sistem online. Penghitungan BPHTB secara online menyertakan kolom nilai transaksi dan mekanisme penghitungan sesuai dengan peraturan yang berlaku, sehingga secara otomatis setelah input data nilai transaksi akan muncul perhitungan dan jumlah BPHTB yang harus dibayarkan.

Penyetoran BPHTB secara online berdasarkan kepada Peraturan Walikota Denpasar Nomor 17 Tahun 2016, mempergunakan sistem self assessment system. Sistem ini mengedepankan peranan wajib pajak secara mandiri melaksanakan berbagai proses penyetoran pajak. Self assessment system merupakan salah satu penerapan dari asas efsiensi. Secara konseptual self assessment system memberi wewenang kepada wajib pajak untuk menghitung, menyetor dan melaporkan sendiri pajak yang terutang; dan fiscus tidak ikut campur serta hanya menjalankan fungsi pengawasan. ${ }^{6}$

Kajian yuridis mengenai penyetoran BPHTB di Kota Denpasar terdapat perbedaan, menurut Perda Kota Denpasar Nomor 7 Tahun 2010 wajib pajak menyetorkan BPHTB terhutangnya secara manual sedangkan Peraturan Walikota Denpasar Nomor 17 Tahun 2016, wajib pajak menyetorkan secara online dengan prinsip self assessment system. Mengacu kepada teori hierarki peraturan perundang-undangan dari Hans Kelsen yang menyatakan bahwa norma hukum yang lebih rendah tidak boleh bertentangan dengan norma hukum yang lebih tinggi ${ }^{7}$, namun nampaknya Peraturan Walikota Denpasar Nomor 17 Tahun 2016 memberikan sebuah efisiensi melalui mekanisme online yang dapat memudahkan proses penyetoran BPHTB bukan untuk menegasikan proses penyetoran yang dirumuskan pada Perda Kota Denpasar Nomor 7 Tahun 2010.

Perbedaan mekanisme penyetoran menjadi hal yang melatarbelakangi diterbitkannya Peraturan Walikota Denpasar Nomor 17 Tahun 2016. Rangkaian penyetoran secara manual yang memakan waktu panjang dapat dipersingkat. Koneksitas secara online antar instansi terkait, dapat mempermudah masyarakat untuk melakukan penyetoran BPHTB, sehingga kewajiban masyarakat untuk melalui birokrasi yang panjang sudah tidak perlu dilakukan.

\subsection{Prosedur Penyetoran Bea Perolehan Hak Atas Tanah dan Bangunan secara online}

Objek perolehan hak pada BРHTB merupakan tanah dan bangunan. Tanah yang menjadi objek peralihan hak merupak anugrah Tuhan yang memiliki multifungsi. Fungsinya antara lain pemenuhan kebutuhan dasar yaitu kebutuhan papan, memiliki fungsi sosial, serta berfungsi sebagai alat investasi jika ditinjau dari sektor ekonomi. Tanah sebagai alat investasi menandakan bahwa tanah dapat memberikan keuntungan

\footnotetext{
${ }^{6}$ Nugroho, A.D. (2011) Kedudukan Asas Efisiensi Pemunguan Pajak Dalam Hukum Acara Perpajakan di Indonesia. MIMBAR HUKUM Edisi Khusus. h.1-237.

${ }^{7}$ Fajarwati, M. (2018) Konstitusionalitas Ketetapan Majelis Permusyawaratan Rakyat Dalam Hierarki Peraturan Perundang-Undangan. Jurnal Hukum \& Pembangunan. 48(1). h.75.
} 
yang besar bagi pemiliknya maka wajarlah jika menunaikan pembayaran pajak dengan memberikan sebagian dari keuntungan yang bernilai ekonomis kepada negara melalui penyetoran BPHTB.

Pasca diterbitkannya Peraturan Walikota Denpasar Nomor 17 Tahun 2016 Tentang Tata Cara Pelaksanaan Pembayaran dan Pelaporan Bea Perolehan Hak Atas Tanah dan Bangunan (BPHTB) secara online, maka pembayaran BPHTB mempergunakan bantuan teknologi informasi dan mempergunakan satu sistem jaringan yang terintergrasi secara langsung dengan instansi terkait yang dalam hal ini adalah Dinas Pendapatan Kota Denpasar selaku penyelenggara sistem.

Indonesia memiliki Undang-Undang Nomor 19 Tahun 2016 Tentang Perubahan atas Undang-Undang Nomor 11 Tahun 2008 Tentang Informasi dan Transaksi Elektronik (UU ITE) pasal 1 angka 3 undang-undang ini menyebutkan tentang pengertian dari teknologi informasi yaitu suatu teknik untuk mengumpulkan, menyiapkan, menyimpan, memproses, mengumumkan, menganalisis, dan/atau menyebarkan informasi. Beranjak dari pengertian tersebut untuk penerapannya maka dibutuhkan media seperangkat computer yang dapat mengolah data, sistem jaringan untuk menghubungkan computer satu dengan yang lain dan teknologi informasi dan komunikasi yang bertujuan sebagai sarana publikasi dan akses data.

Beranjak dari hal diatas proses penyetoran BPHTB di kota Denpasar diharapkan dapat mengaplikasikan perkembangan teknologi informasi dan komunikasi yang bertujuan untuk memudahkan pelayanan kepada wajib pajak. Sehingga diberlakukanlah mekanisme online pada proses penyetoran BPTHB di Kota Denpasar. Mekanisme dari proses penyetoran BPHTB secara online dilaksanakan dengan beberapa tahapan.

Tahapan-tahapan mengakses BPHTB online, pertama diawali dengan masuk pada website www.e-pajak.denpasarkota.go.id setelah itu melakukan login sesuai dengan akun yang dimiliki oleh PPAT Kota Denpasar. Kedua memilih perbuatan hukum yang akan di akses BPHTB lalu masukan NOP (Nomor Objek Pajak). Proses ketiga adalah input data obyek, pemberi hak dan penerima hak serta lampiran. Lampiran yang diinput antara lain data tanah berupa SHM (Sertifikat Hak Milik, bukti bayar PBB (Pajak Bumi dan Bangunan) tahun terbaru, daftar lunas PBB tiap tahunnya, KTP (Kartu Tanda Penduduk) pemberi hak dan Kartu Keluarganya, KTP penerima hak dan Kartu Keluarganya. Terdapat perbedaan lampiran disetiap peralihan hak, seperti jualbeli melampiran bukti transaksi dan surat pernyataan harga yang dibuat dibawah tangan oleh penjual dan pembeli, untuk hibah melampirkan akta hibah dan untuk waris melampirkan akta kematian/ surat keterangan kematian, surat pernyataan waris, surat pernyataan silsilah keluarga.

Proses keempat yaitu kirim SPTPD-BPHTB (Surat Pemberitahuan Pajak Daerah Bea Perolehan Hak Atas Tanah dan Bangunan), apabila terdapat beberapa kekeliruan maka akan diadakan revisi, dan setelah tidak ada kesalahan blangko SPTPD-BPHTB dicetak serta formulir pembayarannya. Selanjutnya dilanjutkan dengan pembayaran di BPD.

Setelah menyelesaikan proses pembayaran maka terdapat proses penelitian berkas oleh staff dari Dispenda Kota Denpasar, pada sistem online terdapat menu pilihan penelitian. Syarat untuk dapat melakukan penelitian adalah melampirkan blangko SSB, bukti bayar dari BPD dan memasukkan data Pajak Penghasilan (PPh) yang juga wajib di bayarkan. Pajak penghasilan dikenakan untuk proses jual - beli bagi penjual. Sedangkan pada proses waris dan hibah tidak membayar PPH. Proses setelah 
melakukan input data yakni melakukan pengecekan tanggal untuk kepastian hadir di Dispenda Kota Denpasar dan jadwal harus dipastikan tersedia (ditandai dengan kolom tanggal yang berwarna biru muda). Selanjutnya, dilakukan penyetoran berkas sesuai tanggal yang dipilih untuk berikutnya dilakukan penelitian oleh Dispenda Kota Denpasar.

Proses yang terakhir adalah meminta legalisir kepala Kepala Kantor Dispenda Kota Denpasar. Proses legalisir dilakukan setelah pembayaran di BPD dan wajib pajak serta PPAT menandatangani blangko SPTPD-BPHTB. Setelah dilegalisir maka selesailah proses penyetoran BPHTB secara online dan salah satu proses peralihan hak atas tanah terpenuhi.

Jadi dapat disimpulkan proses penyetoran BPHTB secara online terbagi dalam beberapa tahapan. Tahapan tersebut tidak semuanya tahapan yang mempergunakan media elektronik, tahapan manual seperti pengumpulan data-data fisik yang dipergunakan untuk penelitian lalu di akhiri dengan proses legalisir dikerjakan secara manual. Sehingga sistem online tidak dapat berjalan secara menyeluruh terhadap proses penyetoran BPHTB.

\section{Kesimpulan}

Peraturan Walikota Denpasar Nomor 17 Tahun 2016 Tentang Tata Cara Pelaksanaan Pembayaran dan Pelaporan Bea Perolehan Hak Atas Tanah dan Bangunan (BPHTB) secara online dibuat atas dasar pertimbangan memudahkan masyarakat untuk melakukan pembayaran terhadap Bea Perolehan Hak Tanah Bangunan baik karena traksaksi jual-beli, waris dan hibah wasiat. Proses penyetoran BPHTB secara online terbagi dalam beberapa tahapan. Tahapan tersebut tidak semuanya tahapan yang mempergunakan media elektronik, tahapan manual seperti pengumpulan data-data fisik yang dipergunakan untuk penelitian lalu di akhiri dengan proses legalisir dikerjakan secara manual. Sehingga sistem online tidak dapat berjalan secara menyeluruh terhadap proses penyetoran BPHTB.

\section{Daftar Pustaka}

Buku

Rusjdi, M. (2005). PBB, BPHTB \& BEA MATERAI; Pajak Bumi dan Bangunan, Bea Perolehan Hak atas Tanah dan Bangunan, \& Bea Materai. Jakarta: PT. Indeks.

Siahaan, M.P. (2003). Bea Perolehan Hak Atas Tanah dan Bangunan. Jakarta:Raja Grafindo Persada

\section{Jurnal}

Sidik, S. (2013). Dampak Undang-undang Informasi dan Transaksi Elektronik (ITE) Terhadap perubahan Hukum dan Sosial Dalam Masyarakat. Jurnal Ilmiah WIDYA Fakultas Hukum Universitas Bhayangkara Jakarta Raya, 1(1) 2338-3321.

Sundary, R.I. (2018). Pengalihan Bea Perolehan Hak Atas Tanah dan Bangunan (BPHTB) dari Pajak Pusat Menjadi Pajak Daerah Sebagai Upaya Peningkatan Pendapatan Asli Daerah (PAD). Aktualita 1(1). 279-294.

Nugroho, A.D. (2011) Kedudukan Asas Efisiensi Pemunguan Pajak Dalam Hukum Acara Perpajakan di Indonesia. MIMBAR HUKUM Edisi Khusus.

Fajarwati, M. (2018) Konstitusionalitas Ketetapan Majelis Permusyawaratan Rakyat Dalam Hierarki Peraturan Perundang-Undangan. Jurnal Hukum \& Pembangunan. 48(1). 


\section{Peraturan Perundang-Undangan:}

Indonesia, Undang-Undang Nomor 20 Tahun 2000 Tentang Perubahan Atas UndangUndang Nomor 21 Tahun 1997 Tentang Bea Perolehan Hak Atas Tanah dan Bangunan (Lembaran Negara Republik Indonesia Tahun 2000 Nomor 130, Tambahan Lembaran Negara Republik Indonesia Nomor 3988)

Indonesia, Undang-Undang Nomor 19 Tahun 2016 Tentang Perubahan atas UndangUndang Nomor 11 Tahun 2008 Tentang Informasi dan Transaksi Elektronik (Lembaran Negara Republik Indonesia Tahun 2016 Nomor 251, Tambahan Lembaran Negara Republik Indonesia Nomor 5952)

Indonesia, Peraturan Daerah Kota Denpasar Nomor 7 Tahun 2010 Tentang Bea Perolehan Hak Atas Tanah dan Bangunan (Lembaran Daerah Kota Denpasar Tahun 2010 Nomor 7)

Indonesia, Peraturan Walikota Denpasar Nomor 17 Tahun 2016 Tentang Tata Cara Pelaksanaan Pembayaran dan Pelaporan Bea Perolehan Hak Atas Tanah dan Bangunan (BPHTB) secara online (Berita Daerah Kota Denpasar Tahun 2016 Nomor 17). 